\title{
Enhancing Literary Competence Through Critical Oriented Reading Strategies
}

\author{
Atefeh Mozafari \\ Department of English Language and Literature, Islamic Azad University, Ayatollah Amoli Branch, Iran \\ Hamed Barjesteh (Corresponding author) \\ Department of English Language and Literature, Islamic Azad University, Ayatollah Amoli Branch, Iran \\ E-mail: ha_bar77@yahoo.com
}

\author{
Received: 04-08-2016 \\ Accepted: $19-10-2016$ \\ Advance Access Published: November 2016 \\ Published: 10-12-2016 \\ doi:10.7575/aiac.ijalel.v.5n.7p.168 \\ URL: http://dx.doi.org/10.7575/aiac.ijalel.v.5n.7p.168
}

\begin{abstract}
This study investigates the impact of critical oriented reading strategies on Iranian EFL male and female students' literary competence (LC). In so doing, 109 homogenized male and female college students of English Literature were screened out of 160 participants due to administering Oxford Placement Test (OPT) among them. The selected participants were randomly assigned into critical (experimental) and non-critical (control) group. They were subsequently divided into male and female groups. All groups were given a novel, Jane Eyre, to read. Then the subjects were given the same pre-post test in the form of LC questionnaire aimed to determine their level of LC before and after the intervention. During the intervention, participants in the critical group were taught and encouraged to use critical reading strategies (CRSs). However, the non-critical group was taught the conventional method of reading. The results indicated a significant difference between learners' LC before and after the intervention. However the LC difference was not statistically significant in term of gender. This study provides more evidence for the importance of CRSs that apparently empower students to know, explain, analyze and answer the questions that arise in a text which leads eventually to a progress in LC of the learners.
\end{abstract}

Keywords: Critical Reading Strategies, EFL Learners, Literary Competence, Reading Comprehension, Gender

\section{Introduction}

The In the realm of teaching English language, conventional methods based on noncritical approaches encourage learners' passivity and adoption to the knowledge transmitted to them by instructors. (Abednia, 2015). Likewise, reading classes mostly focus on the literal comprehension of lexical items that is directly stated in the text, while the conceptual perception of the content are often neglected. (Burns, Roe, \& Ross, 1999). In fact, reading which should be a wisely procedure and described as an active process of conception, is converted to just a flow of collecting raw entries from the text (Talebinejad \& Matou, 2012). Neranjani (2011) believes that literal reading is frustrating for students and cannot be a kind of challenging reading which makes them use their creativity in order to find subtle ideas hidden through the lines. That would lead to a desperate situation in which students encountered only with a plenty of vague, ambiguous and scattered items that are vital to be clarified for comprehending a literary work. The reason behind is that they suffer from lack of LC which is resulted from a lack of in depth reading comprehension which differs from simple understanding of a content.

Similarly Khabiri and Pakzad (2012) mention that literature reading courses often make students find out just about literal meaning and form-based items while focusing on the surface reading. They maintain that it takes away students creativity and talents and just inhibit thinking and critical reading. Recent studies lead to a growing focus on critical reading ability that apparently empower students to know, explain, analyze and answer the questions that arise in text (Waters, 2000 as cited in Fahim, Barjesteh \& Vaseghi, 2012). This in turn results in a comprehensive perception of a work proceeding by an upward jump for students in the field of LC (Paesani, 2005). Akin, Koray and Tavukcu (2015, p.2445) assert that "an individual's ability to keep what he has read in his mind for a long time can only be possible with critical reading which requires a process of active communication where comments and evaluation on the text are conducted". They argue that in critical reading, the context being read, forms the foundation for other readings and even if the reading process finishes, the meaning transmission of the text will be still in progress. In critical approaches, learners are encouraged to involve texts in a questioning method, receive challenging knowledge and reconstruct the issue in a way that is consistent with their past experiences (Abednia, 2015). In adition Mozafari and Barjesteh (2016) maintained that

CRS can pave the ground for the learners to foster their literal, personal, social development and self-awareness. They provided empirical support for the positive effect of CRSs on enabling learners to recognize, make clear, compare and solve ambiguities in the texts. 
Considering Iranian EFL curriculum, it is found out that almost all of the literature reading courses are suffering from the same problem of form-based instruction of literary text all through the course. Actually, what is happening in Iranian EFL literature courses is merely the act of reading, not comprehending, which mostly deals with the language form rather than content (Ghahremani-Ghajar \& Mirhosseini, 2005). Likewise, Ebrahimi and Rahimi (2013) come to the conclusion that EFL learners take up a submissive condition when dealing with texts. It shows that there is a gap between the teaching process and objectives and the abilities the students have acquired. The study of literature seeks critical reading procedure on the part of learners which leads to encourage imagination and creativity in them. In this way, they can discover and apprehend the underlying and deep literary concepts of the texts and finally increase their level of LC which is one of the major needs in successful literary courses (Neranjani, 2011).

Due to the inefficiency of traditional methods of reading courses in second language training, which leads to the gap between reading class targets and its impact on the promotion of students' LC, this study is an attempt to seek a helpful strategy to enable Iranian EFL learners to overcome the difficult task of comprehending a literary text and to raise their LC. The main purpose of this research is to explore the impact of critical oriented reading strategies (CRS) on Iranian EFL students' LC. In other words, it investigates whether incorporating CRS to a novel text help students develop their LC and also examine its differential impact on male and female separately. To fulfill the purpose of the research the following questions were developed:

Q 1. Does critical reading of literary texts improve LC of Iranian EFL students?

Q 2. Does the effect of CRS on LC differ between male and female learners?

\section{Method}

A total number of 109 participants, 41 male and 68 female, comprised the subject pool of the study. They were students of English language and Literature of Azad University of Tehran North Branch which were selected from an upper intermediate level. They were all native speakers of Persian language with one to five years of English language learning before taking up the English literature. They were aged between 22 and 30, but the average age was 25 .

\subsection{Instruments}

To fulfill the purposes of this research the following tools were used: (a) An Oxford Placement Test (OPT) and (b) LC questionnaire (pre-test and post-test).

\subsection{Oxford Placement Test (OPT)}

To check the students' proficiency level an Oxford Placement Test (OPT) would be administered among them. The OPT was a reliable and efficient means of grading and placing students into classes and measures practically the following aspects of students' English proficiency: (a) grammar; (b) vocabulary; and (c) sentence recognition. The test was comprised of 60 multiple choice items for measuring the knowledge of students' grammar, vocabulary and sentence recognition. Those who scored one standard deviation above or below the mean would be considered the subject of the research.

\subsection{LC Questionnaire}

The second instrument was a LC questionnaire adopted from Neranjani (2011). It was utilized as a pre-test to discover the subjects' level of LC prior to the intervention programme. The same questionnaire also was utilized as a post-test to determine developmental levels of learners in terms of their LC after the treatment. The LC questionnaire comprised six subsections which practically measure the six levels of LC as followed: (a) understanding implicit and explicit meanings of words in the text; (b) demonstrating genre of the text through quotations; (c) relating the text to the historical and social factors; (d) recognizing the theme of the text; (e) realizing values and attitudes conveyed in the text; (f) mentioning point of view of the text.

\subsection{Procedure}

In order to explore whether critical reading of literacy text can improve Iranian EFL learners'LC, students were exposed to the novel of Jane Eyre. To tap their proficiency level, an OPT was administered among the subject pool. Those who scored one standard deviation above or below the mean were considered as the subject of the present research. Next, they were randomly divided into two sections: critical and non-critical. Both groups were administered the same kind of novel as the literary text. The novel for both groups was the same- in terms of content.

More precisely, the research was divided into three phases. At first, all students in critical and non-critical group were given a pre test of an LC questionnaire developed by Neranjani (2011). It was aimed to determine the subjects' level of LC prior to the intervention programe. It was developed to assess six levels of LC of students.

In the second part, all learners in critical group received their treatment in the form of different kinds of CRS listed as: previewing, questioning, contextualizing, summarizing and outlining, assessing a topic, and surveying similar reading. Next, the corresponding CRS was proposed to the critical group. It was accompanied by a detailed description about each strategy and how to apply them to a text in order to have a critical reading of the text. The students in non-critical group then were given the traditional instruction of reading comprehension as the treatment, entailing reading the text, decoding and understanding each word separately without linking them together into meaningful ideas (McNamara, 2007) and guessing the meaning of new words. 
In the third phase of the research, the same LC questionnaire was delivered to critical and non-critical group as the posttest. The questionnaire was aimed to determine the levels of students LC development after training. The data were collected and subjected to analysis as what follow.

\section{Results}

To check the students' proficiency level, an OPT was administered among 160 students from Azad university TehranNorth branch. Table 1 shows the result of OPT.

Table 1. The Descriptive Statistics of the OPT

\begin{tabular}{llllll}
\hline & $\mathrm{N}$ & Minimum & Maximum & Mean & Std. Deviation \\
\hline Opt & 160 & 17.00 & 56.00 & 35.15 & 8.82 \\
Valid N (listwise) & 160 & & & & \\
\hline
\end{tabular}

In order to select the sample, all given scores were analyzed. More precisely, those who scored one standard deviation above or below the mean were considered the subject of the present research. Of the total participants, 109 learners were considered the subject pool of the present study. Table 2 presents the descriptive statistics of the target subject.

Table 2. The Descriptive Statistics of Sample Selection

\begin{tabular}{llllll}
\hline & $\mathrm{N}$ & Minimum & Maximum & Mean & Std. Deviation \\
\hline Opt & 109 & 27.00 & 44.00 & 34.70 & 4.62 \\
Age & 109 & 22.00 & 30.00 & 23.59 & 1.69 \\
Valid N (listwise) & 109 & & & & \\
\hline
\end{tabular}

Next, out of 109 students, 54 students were randomly assigned to the critical group including 20 male and 34 female and 55 students were assigned to the non-critical group including 21 male and 34 female. Table 3 illustrates the descriptive statistics of male/female groups.

Table 3. The Descriptive Statistics of male/female groups

\begin{tabular}{lllll}
\hline & & \multicolumn{2}{l}{ Gender } & \\
\cline { 3 - 5 } & & male & Female & \\
\hline \multirow{2}{*}{ Group } & Critical & 20 & 34 & 54 \\
\multirow{2}{*}{ Total } & non-critical & 21 & 34 & 55 \\
& & 41 & 68 & 109 \\
\hline
\end{tabular}

Then, the students were asked to read the Jane Eyre novel written by Charlotte Bronte, prior to a pre-test administration on it. The process of reading was monitored periodically in the sense that, during 5 sessions each of which comprise 22 students came and summarized assigned chapters for other learners to make sure that they were really involved in the process of reading. After that, they sat for the LC pre-test based on Jane Eyre. Next, both critical and non-critical groups received their related treatment for 6 sessions which lasted for 3 weeks. After the period of treatment both groups took the same LC post-test.

To estimate the reliability of the LC test Cronbach alpha coefficient was run. The results indicated that LC test enjoyed the reliability of 0.77 .

Table 4 shows the general descriptive statistics for students' scores obtained through pre and also post test. The minimum score of 109 learners in pre-test was found to be 5 and the maximum was 13 with the range of 8 between the least and the last score. Generally the mean for 109 students in pre-test was 9.6 and the standard deviation was 1.9 . Accordingly, in post-test the lowest score was 7 and the highest one was discovered to be 20 with the range of 13 . The mean for all students in the post-test was 13.2 and the standard deviation was 3.6.

Table 4. Descriptive Statistics of Scores in Pre-test and Post-test

\begin{tabular}{llllllll}
\hline & $\mathrm{N}$ & Range & Minimum & Maximum & Mean & Std. Deviation & Variance \\
\hline Pretest & 109 & 8.00 & 5.00 & 13.00 & 9.64 & 1.93 & 3.73 \\
Posttest & 109 & 13.00 & 7.00 & 20.00 & 13.29 & 3.61 & 13.08 \\
Valid N (listwise) & 109 & & & & & & \\
\hline
\end{tabular}


Furthermore, the table 5 displays the statistical results of pre-test and post-test of critical and non-critical groups descriptively. For the critical group the scores in the pre-test started from 5 as the lowest score to 13 as the highest score with the range of 8 while in the post-test the minimum score was 14 and the maximum was 20 with the range of 6 . The mean and the standard deviation in same group in pre-test were 9.6 and 1.9 while the mentioned scores in the post-test were 16.4 and 1.7. Accordingly, for the non-critical group the scores in the pre-test initiates from 5 as the lowest score and proceeded to 13 as the highest one with the range of 8 whereas in the post-test, scores were distributed along the continuum of 7 as the minimum score till 14 as the maximum with the range of 7 . Also, the mean and the standard deviation in the same group in pre-test were 9.6 and 1.9 while the mentioned scores in the post-test were 10.1 and 1.7.

Table 5. Descriptives Statistics of Scores in Pre and Post-test Based on Groups

\begin{tabular}{|c|c|c|c|c|c|c|c|c|}
\hline & & $\mathrm{M}$ & $\mathrm{V}$ & Std. D & Min & Max & $\mathrm{R}$ & Std. E \\
\hline \multirow{2}{*}{ Pre-test } & Critical Group & 9.62 & 3.74 & 1.93 & 5.00 & 13.00 & 8.00 & 0.26 \\
\hline & \multicolumn{2}{|c|}{ Non-critical Group9.65 } & 3.78 & 1.94 & 5.00 & 13.00 & 8.00 & 0.26 \\
\hline \multirow{2}{*}{ Post-test } & Critical Group & 16.48 & 3.04 & 1.74 & 14.00 & 20.00 & 6.00 & 0.23 \\
\hline & \multicolumn{2}{|c|}{ Non-critical Group $_{10.16}$} & 3.02 & 1.74 & 7.00 & 14.00 & 7.00 & 0.23 \\
\hline
\end{tabular}

To answer the first null hypothesis stating that critical reading of literary texts doesn't improve LC of Iranian EFL learners, a paired-sample t-test was administered. The raw scores which were gained from the pre and post-test were analyzed by SPSS. The mean, standard deviation and differences of means were also calculated for all groups. Significance of difference between the mean scores of the critical group was examined by applying paired sample t-test.

Table 6 illustrates the descriptive statistic administered to compare the mean scores of critical group in pre and post-test.

Table 6. Descriptive Statistics of Mean Scores for Critical Group in Pre and Post-test

\begin{tabular}{llllll}
\hline \multicolumn{2}{l}{ Paired Samples Statistics } & & & \\
\hline & Mean & $\mathrm{N}$ & Std. Deviation & Std. Error Mean \\
\hline \multirow{2}{*}{ Pair 1 } & pretest & 9.62 & 54 & 1.93 & .26 \\
& posttest & 16.48 & 54 & 1.74 & .23 \\
\hline
\end{tabular}

In order to examine the significant difference between pre and post-test in critical group, paired-sample t-test was performed. The result which is presented in table 7 indicates a significant difference between pre and post-test of the critical group. The significance level was less than the significant value which is $0.05(\mathrm{t}=-21.7, \mathrm{Sig}=000)$. Thus, the first null hypothesis was disapproved.

Table 7. Paired Sample t-test for Pre-test and Post-test Difference in Critical Group

\begin{tabular}{|c|c|c|c|c|c|c|c|c|}
\hline & \multicolumn{5}{|c|}{ Paired Differences } & \multirow{4}{*}{$\mathrm{T}$} & \multirow{4}{*}{$\mathrm{df}$} & \multirow{4}{*}{ Sig. } \\
\hline & \multirow{3}{*}{ Mean } & \multirow{3}{*}{$\begin{array}{l}\text { Std. } \\
\text { Deviation }\end{array}$} & \multirow{3}{*}{$\begin{array}{l}\text { Std. } \\
\text { Error Mean }\end{array}$} & \multicolumn{2}{|c|}{$95 \%$ Confidence } & & & \\
\hline & & & & $\begin{array}{l}\text { Interval } \\
\text { Difference }\end{array}$ & the & & & \\
\hline & & & & Lower & Upper & & & \\
\hline Pair1 & 6.85 & 2.31 & .31 & -7.48 & -6.21 & -21.72 & 53 & 000 \\
\hline
\end{tabular}

To answer the second null hypothesis stating that there is not any significant difference between male and female learners' LC, a covariance analysis was performed. The analysis which was used to answer this question was a two-way ANCOVA was run.

In son doing a number of assumption should be met. The first assumption was the internal consistency of covariate (LC pre-test) which was necessary to be in an accepted range. The result of Cronbach alpha ,0.77, indicates the test is within an eligible domain.

The second assumption was that of linearity of the research parametric data. As figure 1 illustrates, it can be seen a linear relationship between the dependent variable and the covariate throughout all groups. Therefore, the second vital assumption was also met. 


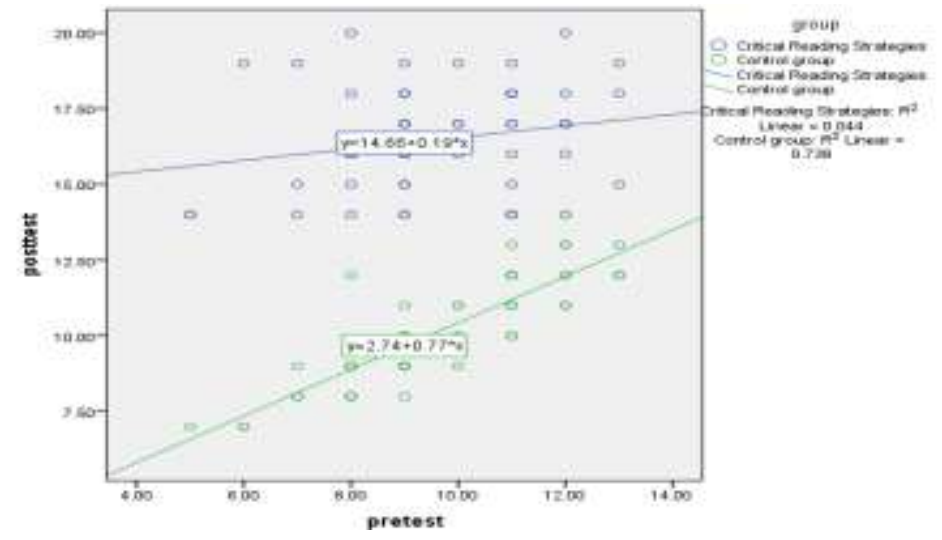

Figure 1. Linear relationship between dependent variable and covariate

The last presumption needed was the homogeneity of regression slopes. As table 8 shows, the significance for interaction effect (group*gender) is greater than $0.05(\mathrm{f}=0.988, \mathrm{sig}=0.09)$. Therefore, there is no significance difference between participants and all of them are homogeneous so that they are basically the same.

Table 8. Tests of Between-Subjects Effects for the Homogeneity of Regression Slopes

\begin{tabular}{|c|c|c|c|c|c|}
\hline \multicolumn{6}{|c|}{ Dependent Variable: posttest } \\
\hline Source & $\begin{array}{l}\text { Type III } \\
\text { Squares }\end{array}$ & $\mathrm{f}$ & Mean Square & $\mathrm{F}$ & Sig. \\
\hline Corrected Model & $1215.46^{\mathrm{a}}$ & 3 & 405.15 & 215.79 & .00 \\
\hline Intercept & 315.55 & 1 & 315.55 & 168.06 & .00 \\
\hline Group & 147.89 & 1 & 147.89 & 78.76 & .00 \\
\hline Gender & 92.44 & 1 & 92.44 & 49.23 & .00 \\
\hline group * gender & 33.77 & 1 & 3.77 & .98 & .09 \\
\hline Error & 197.14 & 105 & 1.87 & & \\
\hline Total & 20675.00 & 109 & & & \\
\hline Corrected Total & 1412.60 & 108 & & & \\
\hline
\end{tabular}

a. $\mathrm{R}$ Squared $=.86$ (Adjusted R Squared $=.85$ )

The following table firstly indicates descriptive statistics of post-test for both groups as far as the gender are concerned. Totally, the amount of mean which is computed to be 13 is the same for both males and females.

Table 9. Descriptive Statistics of Scores for Critical and Non-Critical Group Based on Gender

\begin{tabular}{lllll}
\hline Dependent Variable: posttest & & & & \\
\hline Group & gender & Mean & Std. Deviation & $\mathrm{N}$ \\
\hline critical group & male & 16.45 & 1.66 & 20 \\
& female & 16.50 & 1.81 & 34 \\
non-critical group & Total & 16.48 & 1.74 & 54 \\
\cline { 2 - 5 } & male & 10.42 & 1.88 & 21 \\
& female & 10.00 & 1.65 & 34 \\
Total & Total & 10.16 & 1.74 & 55 \\
& male & 13.36 & 3.51 & 41 \\
& female & 13.25 & 3.69 & 68 \\
& Total & 13.29 & 3.61 & 109 \\
\hline
\end{tabular}

Then, as indicated in table 10 the results were subjected to analysis of two-way ANCOVA to probe the second rerserach question. Regarding the sig. value, it is a significant main effect for "group" $(\mathrm{f}=456.2$, sig=0.000), but the main effect for "gender" is not significant $(\mathrm{f}=0.023$, sig=0.879). It means that there is a meaningful and significant difference among critical group and non-critical group but there is not meaningful difference among male and female learners. Moreover, there is no significant interrelation between group and gender which means that critical reading strategy has the same effect upon male and female LC and there is not meaningful difference between male and female learners' LC $(\mathrm{f}=0.589$, sig= 0.445). Hence, the second null hypothesis is confirmed which means that the impact of CRS does not differ between male and female learners' LC. 
Table 10. Tests of Between-Subjects Effects for the Post-test

\begin{tabular}{|c|c|c|c|c|c|c|c|}
\hline \multicolumn{8}{|c|}{ Dependent Variable: posttest } \\
\hline Source & $\begin{array}{l}\text { Type III } \\
\text { Squares }\end{array}$ & ff & Mean Square & $\mathrm{F}$ & Sig. & $\begin{array}{l}\text { Partial } \\
\text { Squared }\end{array}$ & \\
\hline Corrected Model & $1183.05^{\mathrm{a}}$ & 4 & 295.76 & 133.99 & .00 & .83 & \\
\hline Intercept & 309.38 & 1 & 309.38 & 140.16 & .00 & .57 & \\
\hline Pre & 93.03 & 1 & 93.03 & 42.15 & .00 & .28 & \\
\hline Group & 1006.55 & 1 & 1006.55 & 456.02 & .00 & .81 & \\
\hline Gender & .05 & 1 & .052 & .02 & .87 & .00 & \\
\hline group $*$ gender & 1.30 & 1 & 1.30 & .58 & .44 & .00 & \\
\hline Error & 229.55 & 104 & 2.20 & & & & \\
\hline Total & 20675.00 & 109 & & & & & \\
\hline Corrected Total & 1412.60 & 108 & & & & & \\
\hline
\end{tabular}

a. R Squared $=.83$ (Adjusted $\mathrm{R}$ Squared $=.83$ )

\section{Discussion}

The first research question aimed to probe whether critical reading of literary texts improve Iranian EFL learners LC. Throughout the course, all students in critical group were instructed and encouraged to incorporate a number of strategies while learners in non-critical group were taught the traditional methods. By applying statistical analysis, the first null hypothesis was rejected that is critical reading of literary texts improve LC of Iranian EFL students.

The second research question was an attempt to investigate whether there is any significant difference among male and female students' LC. By conducting an analysis of covariance and also by studying the gain scores of two groups regarding males and females, it was discovered that there was not no remarkable difference among male and female LC of learners.

It is noteworthy that the findings of this research were supported by many studies, some of which are outlined below, whereas there are also opposing ideas which are in contrast with the results of this research. For instance the result of this study is harmonized with Johnson (2002) believes that critical approaches provide the person with the possibility to reach the most comprehensive understanding of literary resources. Yudkin (2006, p. 101) also, while emphasizing on the importance of critical reading, states that "when we read critically, we are always alert, always on the look out for hidden clues, never reliant on the infallibility of the author" which eventually leads students toward activating their LC. Similarly the present result is supported by Kennedy, Fisher and Ennis (1991) who find out that learners of all mental capability levels and language background can derive benefit from critical reading education and so as from LC as the quick result of it. The finding also is in line with Lewis and Smith (1993) who state that critical reading abilities include everybody to learn and apply them to different genres of reading specifically literary works to explore what the underlying layers and facts building up the whole story. Likewise, Shokrpour, Sadeghi and Seddigh (2013) discuss that utilizing CRS has a positive effect on teaching reading comprehension while practiced by Iranian EFL students. Additionally, the research finding is in line with Icmez (2009) exploring different methods in which CRS would be adjusted to prevalent EFL reading courses in order to expand learners' awareness to apply literary comprehension techniques. Koupaee, Rahimi, and Shams (2010) investigate the developmental level of critical reading skills of Iranian EFL learners after instructing CRSs applied to literature. Their findings reveal that ninety percent of learners' critical language knowledge was increased and their motivation also was sarcastically enhanced after being acquainted with critical reading techniques. According to Bosely (2008) some of university instructors believe that the graduates can read critically, while many researches suggest that CRS should be taught explicitly and also reinforced by the help of practice. The result of the study is also harmonized with Danaye Tous, Tahriri and Haghighi (2015) state that it is not significant difference among men and women EFL students' perception of critical reading instruction. But the study result is against with King, Mines and Wood (1990) suggest that the developmental rate of critical reading differ for men and women.

The findings also are in line with Barjesteh, Nasrollahi, and Esmaili (2016) in that CL approach to EFL/ESP classroom can foster the quality of students' language skills. Their dialogue journals were examined qualitatively to explore the possible changes in their modes of writing. The results uncovered that dialogue journals help learners could go beyond a descriptive and personal writing.

\section{Conclusion}

This paper examined CRS to enable Iranian EFL learners both comprehend and uncover the underlying message of a text. By applying CRS to the students engaged in reading a novel text, it became evident that their LC status enhanced, while there was no remarkable difference between male and female in the promotion of LC. The pedagogical implications in this research correspond with the following studies. Burns, Roe and Ross, (1999) criticized most literature reading classes which only focus on the literal comprehension of lexical items which is directly stated in the 
text. Waters (2000) stated that recent trends have led to an increasing emphasis on the role of critical reading technique that supposedly enables students to identify, clarify, evaluate and solve perplexities that arise in reading. Neranjani (2011) believed in Critical reading which can be considered as a tool in the process of analyzing literary works in order to achieve the abstract ideas conveyed throughout the text which leads to a progress in LC of learners. Khabiri and Pakzad (2012) encouraged Integrating reading courses with influential CRS and Abednia (2015) claimed that critical approaches highlight the learners' consciousness and emphasis on self-seeking. Next studies can focus on other components of language skill strategies other than reading, like writing, speaking, and listening which are used daily throughout EFL/ESL classes as an appropriate and accessible tool, toward LC improvement

\section{References}

Abednia, A. (2015). Practicing critical literacy in second language reading. International Journal of Critical Pedagogy, (6)2, 77-94.

Aghagolzadeh, F., \& Tajabadi, F. (2012). A debate on literature as a teaching material in FLT. Journal of Language Teaching and Research, (3)1, 205-210.

Akin, F., Koray, O., \& Tavukcu, K. (2015). How effective is critical reading in the understanding of scientific texts. Procedia - Social and Behavioral, 174, 2444- 2451.

Aksan, N., \& Kisac, B. (2009). A descriptive study: reading comprehension and cognitive awareness skills. ProcediaSocial and Behvioral Science, (1)1, 834-837.doi:10.1016/j.sbspro.2009.01.149

Alden, K. C., Lindquist, J. M., \& Lubkeman, C. A. (2003). Using literature to increase reading motivation. Chicago, IL: Saint Xavier University and Sky light Professional Development Field-Based Master's Program.

Alexander, J. E., \& Filler, R. C. (1976). Attitudes and reading. Newark, Delaware: International Reading Association.

Alptekin, C. (2006). Cultural familiarity in inferential and literal comprehension in L2 reading. System, 34(4). 494-508. doi:10.1016/j.system.2006.05.003

Amer, A. A. (2012). Using literature in reading English as Second/Foreign Language. Tanta, Tanta University Egypt.

Barjesteh, H. Nasrololahi, A., Esmaili, M. R. (2016). Incorporating Principles of CP in an ESP writing classroom: Exploring writing Quality and Learners' Attitudes. Modern Journal of Language Teaching Methods, 6(7)17-23.

Bedel, O. (2011). Literature circles in EFL. The $46^{\text {th }}$ Annual International IATEFL Conference, 1-13.

Bosely, L. (2008). I don't teach reading: Critical reading instruction in composition course. Literacy Research and Instruction, 47, 280-308.

Bronte, C. (1847). Jane Eyre. Oxford: Oxford University Press.

Brumfit, C. J. (1986). Literature and language teaching. Oxford: Oxford University Press.

Brumfit, C. J. (2001). Individual freedom in language teaching: Helping learners to develop a dialect of their own. Oxford: Oxford University Press.

Brumfit, C. J., \& Carter, R. A. (2000). Literature and language teaching. Oxford: Oxford University press.

Burbules, N. C., \& Berk, R. (1999). Critical thinking and critical pedagogy: Relations, differences, and limits. Critical Theories in Education.

Burns, P. C., Roe, B. D., \& Ross, E. P. (1999). Teaching reading in today's elementary schools. USA: Houghton Mifflin Company.

Bury, Liz. (2013, October 8). Reading literary fiction improves empathy, study finds. The Guardian. Retrieved from www.theguardian.com.

Carter, R., \& Long, M. (1990). Testing literature in EFL classes: Tradition and innovation. ELT Journal, 44(3), 215221.

Carter, R., \& Long, M. (1991). Teaching literature. New York: Longman.

Coenen, L. (1992). Literary competence: Usefull concept for literary education or new 'Catch-All Term'?. Spiegel, $10(2), 55-78$.

Culler, J. (1975). Structuralist poetics: Structuralism, linguistics, and the study literature. London: Routledge and Kegan Paul.

Danaye Tous, M., Tahriri, A., \& Haghighi, S. (2015). The effect of instructing critical thinking Through debate on male and female EFL learners' reading comprehension. Journal of the Scholarship of Teaching and Learning, 15(4), 21-40.

Day, R. R., \& Bamford, J. (1998). Extensive reading in the second language classroom. Cambridge University Press. Dewey, J. (1910). How we think. Boston: D.C. Heath and Company.

Dey, S. (2009). A study of literacy competence achieved by students in a text based learning environment. Proceedings of the $2^{\text {nd }}$ International Conference of Teaching and Learning (ICTL).

Dienstag, J. F. (2006). Pessimism: Philosophy, Ethic, Spirit. Princeton: Princeton University Press. 
Ebrahimi, N. A., \& Rahimi, A. (2013). Towards a more efficient EFL reading comprehension classroom environment: The role of content and critical reading. Apples - Journal of Applied Language Studies, 7(2), 1-15.

Erkaya, O. R. (2005). Benefits of using short stories in the EFL context. Asian EFL Journal, 8. 1-13.

Fahim, M., Barjesteh, H., \& Vaseghi, R. (2012). Effects of critical thinking strategy training male/female EFL learners' reading comprehension. English Language Teaching, 5(10), 140-145.

Finch, A. (2012). Bringing classroom-based assessment into the EFL classroom. Applied Research in English. Rep. of Korea Kyungpook National University.

Fishbein, M., \& Ajzen, I. (1975). Belief, attitude, intention, and behavior: An introduction to theory and research. Reading, MA: Addison-Wesley.

Freire, P. (1972). Cultural action for freedom. Harmondsworth: Penguin.

Gajdusek, L. (1988). Toward wider use of literature in ESL: Why and how. TESOL Quarterly, 22(2), 227257.doi: $10.2307 / 3586935$

Ghahremani-Ghajar, S., \& Mirhosseini, S. A. (2005). English class or speaking about everything class: Dialogue journal writing as a critical EFL literacy practice in an Iranian high school. Language, Cultural and Curriculum. 18(3), 286299.

Ghosn, I. K. (2002). Four good reasons to use literature in primary school ELT. ELT Journal, 56(2), 172-179.

Halpern, D. F. (1996). Thinking critically about critical thinking: An exercise book to accompany thought and knowledge: An introduction to critical thinking. Mahvah, NJ: Lawrence Erlbaum Associate, Inc. Publishers.

Halpern, D. F. (1998). Teaching critical thinking for transfer across domains: Disposition, skills, structure, training and meta cognitive monitoring. American psychologists, 53, 449-455.

Harris, A. J., \& Sipy, E. R. (1990). How to increase reading ability. New York: Longman.

Hill, J. (1989). Using literature in Language teaching. London: Modern English Publications.

Icmez, S. (2009). Motivation and critical reading in EFL classroom: A case of ELT preparatory students. Journal of Theory and Practice in Education, 5(2), 123-147. Retrieved from http.//eku.Comu.edu.tr/index.

Isenberg, N. (1990). Literary competence: The EFL reader and the role of the teacher. ELT Journal, 44(3), 181-190.

Izadinia, M., \& Abednia, A. (2010). Dynamics of an EFL reading course with a critical literacy orientation. Journal of Language and Literacy Education, 6(2), 51-67.

Johnson, E. B. (2002). Contextual teaching and learning: What it is and why its her to say. Thousands Oaks, CA: Crowin Press.

Juhana, J. (2012). Psychological factors that hinder students from speaking in English class (A case study in a senior high school in South Tangerang, Banten,Indonesia). Journal of Education and Practice. 3(12), 100 -110.

Kavcar, C., Oguzkan, F., \& Sever, S. (1994). Turkce ogretimi: Turkce ve sinif ogretmenler i icin. Ankara: Engin Yayincilik.

Kennedy, M., Fisher, M. B., \& Ennis, R. H. (1991). Critical thinking: Literature review and needed research. In L. Idol \& B. F. Jones (Eds.), Educational Values and Cognitive Instruction: Implications for Reform (pp. 11-40). Hillsdale,NJ: Erlbaum.

Khatib, M., \& Nasrollahi, A. (2012). Enhancing reading comprehension through short stories in iranian EFL learners. Theory and Practice in Language Studies, 2(2), 240-246.

Khabiri, M., \& Pakzad, M. (2012). The effect of teaching critical reading strategies on EFL learners' vocabulary retention. The Journal of Teaching Language Skills (JTLS). 4(1), 73-106.

Khatib, M., Ranjbar, S., \& Fathi, J. (2012a). The role of literature in EFL classroom from an EIL perspective. Journal of Academia and Applied Studies, 2(2), 12- 21.

Khatib, M., Rezaei, S., \& Derakhshan, A. (2011). Literature in EFL/ESL classroom. English Language Teaching (Canadian Center of Science and Education), 4(1), 201-208.

King, P. M., Wood, P. K. \& Mines, R. A. (1990). Critical thinking among college and graduate Students. The Review of Higher Education, 13(2), 167-186.

Kodama, Keita. (2012). The role of literature in the EFL/ESL classroom revisited: Using literature in communicative language teaching. Aichi Prefectural University Graduate School of International Cultural Studies Journal, 13, 31-56.

Koupaee Dar, Z., Rahimi, A., \& Shams, M. (2010). Teaching reading with a critical attitude: Using critical discourse analysis (CDA) to raise EFL university students' criticallanguage awareness. International Journal of Criminology and Sociology Theory, 3(2), 457-476.

Kurland, D. (2000). Critical reading VS. critical thinking. Retrieved February 10, 2014, from http:// www.criticalreading.com/criticalreadingthinkingtoo.htm.

Lao, C. Y., \& Krashen, S. (2000). The impact of popular literature study on literacy development in EFL: More evidence for the power of reading. System, 28(2), 261-270. 
Lazar, G. (1993). Literature and language teaching. Cambridge: Cambridge University Press.

Lewis, A., \& Smith, D. (1993). Defining higher order thinking. Theory into Practice, 32(3), 131-137.

Littlewood, W. T. (2006). Foreign and second language learning. Cambridge University Press.

Mahboobi, M., \& Kaur, S. (2011). A survey of iranian EFL university students'motivation and interest in intensive reading. Iranian EFL Journal. 7(6), 30-46.

Maley, A. (1989). Down from the pedestal: Literature as resource. In C. J. Brumfit, R. A. Carter \& R. Walker (Eds.) Literature and the learner: Methodological approaches. (pp. 1-9). Modern English Publications and The British Councel.

Maley, A., \& Duff, A. (1991). Literature. Oxford: Oxford University press.

Mangal, S. K. (2005). Advanced educational psychology. New Delhi: Prentice-Hall.

Marshall, L. A., \& Rowland, F. (1998). A guide to learning independently. Buckingham: Open University Press.

McKay, S. (1982). Literature in the ESL classroom. TESOL Quarterly, 16(4), 529-536.

McNamara, D. S. (Ed.). (2007). Reading comprehension strategies: Theory, interventions, and technologies. Mahwah, NJ: Erlbaum.

Mihandoost, Z. (2011). A meta-analysis review: Reading attitude in students with learning disability. Journal of Basic and Applied Scientific research, 1(8), 910-915.

Missori, L. (2007). Applying critical thinking to reading, Longview Community College. Retrieved June 20, 2010, Retrieved from http//www.ss.Critical thinking.html

Mozafari, A., \& Barjesteh, H. (2016). Utilizing Reflective Journal to Raise Critical Language Awareness: A Critical Literacy Practice in a Reading Classroom. Modern Journal of Language Teaching Methods, 6(6)109-118.

Neranjani, E. S., (2011). Enhancing Literary Competence through Activity Based Literature Learning. University of Colomo.

Noaman, N. N. (2013). Literature and language skill. AL-USTATH, Baghdad university, 204(2), 123-134.

Otensoy, A. U. (2011). The effects of the social studies cource, organized for critical reading on students' critical thinking skills. (Unpublished Phd thesis). Gazi University Institute of Educational Sciences, Ankara, Turkey.

Paesani, K. (2005). Literary texts and grammar instruction: Revisiting the inductive presentation. Foreign Language Annuas, 38(1), 15-24.

Paul, R., \& Elder, L. (2006). The miniature guide to critical thinking concepts and tools. Dillon Beach CA: The Foundation for Critical Thinking.

Paul, R. W. (1992). Critical thinking: What, Why, and How? New Directions for Community Colleges, 1992(77), 3-24.

Rahimi, S. (2014). The use of literature in EFL classes. Journal of Academic and Applied Studies, 4(6), 1-12.

Rashtchi, M., \& Aghajanzadeh, M. (2008). Comparative critical reading strategy and writing achievement of Iranian EFL learners. The Journal of Applied Linguistics, 1(2), 117- 130.

Salvin, R. E. (2006). Educational psychology: Theory and practice. New York: Pearson.

Schmidt, S.J. (1982). Foundation for the empirical study of literature: The components of abasic theory (R. de Beaugrande, Trans.). Hamburg: Helmut Buske Verlag.

Shakibaei, G. \& Keivan, S. (2014). The correlation analysis between speaking and listening, reading and writing, and reading and speaking mean band IELTS scores achieved by 2011 from the top 41 countries(academic). Iranian EFL Journal, 10 (1), 338-348.

Shokrpour, N., Sadeghi, A., \& Seddigh, F. (2013). The effect of summary writing as a critical Reading strategy on reading comprehension of Iranian EFL learners. Journal of Studies In Education, 3(2), 127-138. doi: 10.5296/jse.v3i2.2644.2013.05.01

Shrestha, P. N. (2008). Using stories with young learners. In M. Krzanowski (Eds.), Current development in English for academic, specific and occupational purposes. UK: Grant Publishing.

Smith, M. C. (1990). A longitudinal investigation of reading attitude development from childhood adulthood. Journal of Educational Research, 83, 215-219.

Snow, C. E. (2002). Reading for understanding: Toward a research and development program in Reading comprehension. California: RAND.

Talebinejad, M. R., \& Matou, Z. (2012). Teacher-student interaction in EFL reading comprehension contexts at university level: A critical thinking perspective. SAGE Open. Retrieved from http://sgo.sagepub.com.

Torres, C. A. (1999). Critical theory and political sociology of education: Arguments. Critical theory in educational discourse. New York: Routledge.

Towell, J. H. (2000). Motivating students through music and literature. The Reading Teacher, 53(4), 284-289. 
Veeravagu, J., Muthusamy, C., Marimuthu, R., \& Subrayan, A. (2010). Using Bloom’s Taxonomy to gauge students' reading comprehension performance. Canadian Social Science,6(3), 205-212.

Waters, A. (2000). Thinking and language learning. ETL Journal, 60(4), 237-319.

Widdowson, H. G. (1975). Stylistics and the teaching of literature (Applied linguistics and language study). Abingdon. Routledge.

Wigfield, A., \& Guthrie, J. T. (1997). Relations of children's motivation for reading to the amount and breadth of their reading. Journal of Educational Psychology, 89(3), 420-432.

Wiland, S. M., (2009). How to develop literary competence in the English classroom. The Norwegian National Centre for Foreign Languages in Education (The Foreign Language Centre).Retrieved from www.fremmedspraksenteret.no/nor/fremmedspraksenteret/engelsk.

Witte, T., Janssen, T., \& Rijlaarsdam, G. (2006). Literary competence and the literature curriculum. University of Groningen, The Netherlands and University of Amesterdam, Netherlands.

Woolfolk, H. A., \& Murphy, P. K. (2001). Teaching educational psychology to the implicit mind. In R. Sternberg \& B. Troff (Eds.), Understanding and teaching the mind. (pp.145-185). Mahwah, NJ.

Yamashita, J. (2013). Effects of extensive reading on reading attitudes in a foreign language. Reading in a Foreign Language, 25(2), 248-263.

Yudkin, B. (2006). Critical reading: Making sense of research papers in life sciences and medicine. London: Routledge. 